\title{
THE FACTORS INFLUENCING VALUE CREATION OF HALAL LOGISTICS CONCEPTUAL FRAMEWORK DEVELOPMENT
}

\author{
Thapanee RUANGSRIROJ ${ }^{1 *}$ \\ Adisak SUVITTAWAT²
}

\begin{abstract}
Received: June 2021 | Accepted: July 2021 | Published: August 2021
Please cite this paper as: Ruangsriroj, T., Suvittawat, A. (2021) The factors influencing value creation of Halal logistics conceptual framework development, Holistica Journal of Business and Public Administration, Vol. 12, Iss. 2, pp.1-15
\end{abstract}

\begin{abstract}
Halal logistics has an important role in global Muslim consumer's way of life. Muslim countries follow Shariah law strictly. Thus, Halal logistics activities must segregate facilities for halal and nonhalal products. In addition, the world Muslim population has risen steadily. It influences production and export volumes from Thailand to the global trade of halal products increasing. Logistics service providers (LSPS) have been seeking an opportunity for creating a business competitive advantage into new situations. They can create and deliver better benefits to customers than their competitors and simultaneously earn higher profits than the average of other LSPs. A variety and flexibility of logistics activities come together to make services more desirable to the target market. Although many studies have been carried out on the influence of value creation, a part of halal logistics research in Thailand is rare. For the reasons mentioned, the objective of this paper to describe the influencing value creation in halal logistics activities from a literature review to be a conceptual framework development. Establishing the issues concerning value creation of halal logistics causality are best explained by the following resource sharing, innovation solutions, and risk management.
\end{abstract}

Keywords: halal logistics; resource sharing; innovation solution; risk management; value creation

\section{Introduction}

Islam is the second largest religion in the world. Muslim refers to anyone who believes in Islamic principles that Sharia law is applied to Muslims in the way of life. The region with the most Muslims is the Middle East. Other areas with large percentages of Muslims

\footnotetext{
1 School of Management Technology, Suranaree University of Technology, Thailand, thapanee057@gmail.com.

* Corresponding author.

2 School of Management Technology, Suranaree University of Technology, Thailand, adisak@sut.ac.th.
} 
include North Africa, Central Asia, Southeast Asia, South Asia, Sub-Saharan Africa, AsiaOceania, the Americas and Europe, respectively (Muslimpopulation, 2018). In 2010, the world Muslim population are a total of approximately 1.6 million-person or 23.4 percent of the total population in the world. And in 2030, the world Muslim population expect risen to 2.2 million-person or gone up by 3 percent (Luis, Alan, Erin \& Sandra, January 2011). Especially, the Muslim population in Indonesia, Saudi Arabia, United Arab Emirates and Turkey, whose population has a higher average income effect to the ability to spending and awareness to selecting of religious goods for good health and good quality. Accordingly, the demand for halal products has been steadily increasing. Regions with abundant resources saw the opportunity to supply customers demand in the halal market that there is not a Muslim majority country. The global halal market in 2018, the trade of halal global was valued at 326.38 billion dollars, which was a high expansion of 10.6 percent in comparison from 2013 to 2017. It shown a continuous growth (National Food Institute, n.d.). The global halal market is a fragmented market with several country. The country with the most market share is the Brazil followed by India, Russia, the United States, and Argentina respectively. Thailand is ranked 9th exporter of halal products. The core halal products of Thailand include rice, corn, tapioca flour, sugar, biscuits, chicken, shrimp, frozen fish, canned tuna, fruit and vegetable juices, canned fruits, and seasonings (KASIKORN Research Centre, n.d.). The international fragmentation of production effect to Muslim consumers concerns a difference to halal standards in different countries. The term of halal standards is not only finish goods, but it's also refers to supply chain processes from upstream to downstream to obtain products and services as well (Ahmad \& Shariff, 2016). Thus, Exporters seek to logistics outsource in order to manage risks associated with outbound logistics activities and to attend more on their specialized activities. Competitive advantages, customer service-levels improvement, and overall logistics costs reduction can be helping exporters to achieve an effective strategy by logistics outsourcing (Talib, Rahim, Chin \& Hamid, 2017: Tian, Ellinger \& Chen, 2010).

A trade liberalization in services has an effect on increased competition encourages logistics service providers (LSPs) to create values and differences in services from the demand for diversity. As a result, service innovation is an important role to offerings the service differentiation from logistics resources and capabilities. The resource-based logistics (RBL) consists of logistics resources into tangible and intangible such as tools, equipment, technology, knowledge, creativity, and relationships in business networks to produce logistics performance efficiently and customer satisfaction (Alkhatib, Darlington \& Nguyen, 2015: Govindan \& Chaudhuri, 2016: Karia \& Asaari, 2016). Currently competition of logistics service providers (LSPs), a service model is a response to mass market, which focuses on speed and reducing the operating costs affect a flexibility services to response a diversity of customer needs. A competitive opportunity depends on the value that logistics service providers (LSPs) provide to customers rather than basic services (Kilibarda, Andrejic \& Popovic, 2013). Strategic planning is much be required to understanding customer needs by establishing partnerships, customer participation, information sharing, knowledge sharing and others (Peng, Wang, Zahid, Wei \& Elahi, 2020: Pham, Nguyen, McDonald \& Tran-Kieu, 2019). It is customer retention and attracted 
new customers to increasing logistics service users. However, a new services development has a risk management that each operate concurrently to evaluate uncertain situation for prevent problems before it occurs (Moslemi, Hilmola \& Vilko, 2016).

The aim of this paper is to explain the information obtained from a literature review with an emphasis on relationships between resource sharing, innovation solution, risk management and value creation. In this study, a valuable guideline will lead the logistics service entrepreneurs in Thailand to generate new ideas and gain new competitive strategies stepping into the global halal market.

\section{Literature review}

\subsection{Resource-based theory}

Firm resources include all tangible and intangible resources such as assets, capabilities, organizational processes, firm attributes, information, knowledge, etc. which are used to implement value creating strategies to improve efficiency and effectiveness (Etokudoh, Boolaky \& Gungaphul, 2017). Barney (1991) defines resource-based view (RBV) implemented strategies that create value and cannot be duplicated by competitors while they have an approximate resource. Logistics service providers (LSPs) have tangible resources such as information systems, human resource, equipment, etc. and intangible resources such as knowledge, capability, cross-functional teamwork, supply chain management, etc (Lai, Wong, \& Cheng, 2010: Ruiz-Torres, Cardoza, Kuula, Oliver \& RosaPolanco, 2017).

\subsection{Halal Logistics}

Halal logistics concepts are combination activities from the point of origin to the end customers performed in obligation with religion, beliefs, and the Shariah law. Halal logistics activities included warehousing, transferring, sourcing and other that all activities for halal products are segregation from non-halal products until they are delivered safe to end customer. Moreover, during activities must be able to inspect thru processes (Fathi, Zailani, Iranmanesh \& Kanapathy, 2016: Jaafar, Endut, Faisol \& Omar, 2011). Tools are used to handle halal products must not be shared to carry on non-halal products as it will cause adulteration. If it cannot separate, it should be cleaned based on Shariah law before used for halal products then sealed with the halal sticker (Jaafar, Endut, Faisol \& Omar, 2011: Talib, Rahim, Chin \& Hamid, 2017). Accordingly, halal logistics is not a normal logistics activity, but it is blending with religious practices. Thus, the preliminary to managing halal to ensure effectiveness in terms of services must create awareness and knowledge to operators.

\subsection{Value creation}

The appropriate proposal creates a value-added to implementation in target markets how to manufacture and sell the product that exceeds the customers' expectations. The value obtained through logistic activities can be measured in costs, quality, price, time, 
competition, and stockholders value. Accordingly, logistics service value creation can be assessed from 2 perspectives: customer perception and the perception of shareholders (Bernardo \& Farrero, 2015: Cengiz, Radha \& Ronald, 2004: Kilibarda, Andrejic \& Popovic, 2013). Logistics values are more created utility than standard services with remodelling quality and quantity processes. The remodelling processes included packaging, repackaging, label marking, quality control and others to fulfil customer requirements (Bowman \& Ambrosini, 2000: Wong, Lai, Cheng \& Lun, 2015).

\section{Methodology}

This study is looking for published articles from both international and domestic research. Keywords were used to find related to halal logistics, logistics service providers, and value creation. Halal products topic is a special report to use in the study. The conceptual framework has been developed from the publication article years ranging from 1991 to 2020 focusing on value creation from logistics activities based on Islamic concepts. A conceptual framework investigated the relationship with 4 variables: resource sharing, innovative solution, risk management and value creation. All variables to research will be discussed in the five sections below.

Table 1 Resource and its associated features

\begin{tabular}{|c|c|c|c|c|}
\hline Main events & $\begin{array}{c}\text { Main events } \\
\text { Meaning }\end{array}$ & Sub-events & $\begin{array}{l}\text { Sub-events } \\
\text { Meaning }\end{array}$ & Reference \\
\hline \multirow[t]{3}{*}{$\begin{array}{l}\text { Resource } \\
\text { sharing }\end{array}$} & $\begin{array}{l}\text { Collaboration with } \\
\text { other organization } \\
\text { in the supply } \\
\text { chain to plan and } \\
\text { execute } \\
\text { operations }\end{array}$ & $\begin{array}{l}\text { Knowledge } \\
\text { sharing }\end{array}$ & $\begin{array}{l}\text { Transferring } \\
\text { expertise, } \\
\text { knowledge, and } \\
\text { capability to } \\
\text { cooperation }\end{array}$ & $\begin{array}{c}\text { Tarmizi et al., } \\
\text { 2014: Vargo \& } \\
\text { Lusch, 2017: Chih, } \\
\text { Zwikael \& } \\
\text { Restubog, } 2019\end{array}$ \\
\hline & & $\begin{array}{l}\text { Information } \\
\text { sharing }\end{array}$ & $\begin{array}{l}\text { The information on } \\
\text { customer data } \\
\text { sharing with } \\
\text { partnership }\end{array}$ & $\begin{array}{l}\text { Liu et al., 2015: } \\
\text { Wong et al., 2015: } \\
\text { Pham et al., } 2019\end{array}$ \\
\hline & & $\begin{array}{l}\text { Advance } \\
\text { technology } \\
\text { and } \\
\text { equipment }\end{array}$ & $\begin{array}{l}\text { Separation tools } \\
\text { operation between } \\
\text { halal and non-halal } \\
\text { products. The } \\
\text { information } \\
\text { checking feedback } \\
\text { on past activity. }\end{array}$ & $\begin{array}{l}\text { Mohamed, Lim \& } \\
\text { Vincent, 2013: } \\
\text { Ahmad, \& Shariff, } \\
\text { 2016: Masudin, } \\
\text { Fernanda \& } \\
\text { Widayat, } 2018\end{array}$ \\
\hline
\end{tabular}


HOLISTICA Vol 12, Issue 2, 2021, pp.1-15

\begin{tabular}{|c|c|c|c|c|}
\hline \multirow[t]{3}{*}{$\begin{array}{l}\text { Innovative } \\
\text { solution }\end{array}$} & $\begin{array}{c}\text { A new process to } \\
\text { create } \\
\text { organizational } \\
\text { innovation }\end{array}$ & $\begin{array}{l}\text { Organization } \\
\text { factor }\end{array}$ & $\begin{array}{l}\text { Factors driving } \\
\text { organizational } \\
\text { innovation; } \\
\text { resources, } \\
\text { learning, } \\
\text { development and } \\
\text { organization } \\
\text { structure. }\end{array}$ & $\begin{array}{c}\text { Jaafar et al., 2011: } \\
\text { Tan, Razali \& } \\
\text { Desa, 2012: } \\
\text { Ralston, Grawe \& } \\
\text { Daugherty, 2013: } \\
\text { Ruiz-Torres et al., } \\
2017\end{array}$ \\
\hline & & $\begin{array}{l}\text { Environment } \\
\text { factor }\end{array}$ & $\begin{array}{l}\text { Factors driving } \\
\text { innovation from } \\
\text { external } \\
\text { environment; halal } \\
\text { standard, } \\
\text { government policy } \\
\text { and competition. }\end{array}$ & $\begin{array}{c}\text { Tan, Razali \& } \\
\text { Desa, 2012: } \\
\text { Ralston, Grawe \& } \\
\text { Daugherty, 2013: } \\
\text { Tarmizi et al., } \\
2014\end{array}$ \\
\hline & & $\begin{array}{l}\text { Assurance } \\
\text { factor }\end{array}$ & $\begin{array}{l}\text { LSP build trust in } \\
\text { service quality by } \\
\text { customers control }\end{array}$ & $\begin{array}{c}\text { Tan, Razali \& } \\
\text { Desa, 2012: } \\
\text { Othman, Shaarani } \\
\text { \& Bahron, 2016: } \\
\text { Ahmad \& Shariff, } \\
\text { 2016: Chen, Hsu \& } \\
\text { Lee, } 2019\end{array}$ \\
\hline \multirow[t]{3}{*}{$\begin{array}{c}\text { Risk } \\
\text { management }\end{array}$} & $\begin{array}{c}\text { Organization } \\
\text { capabilities to } \\
\text { manage } \\
\text { uncertainty and } \\
\text { customers } \\
\text { distinguishable } \\
\text { variations }\end{array}$ & $\begin{array}{c}\text { Process } \\
\text { design and } \\
\text { planning risks }\end{array}$ & $\begin{array}{c}\text { Proactive risk } \\
\text { management } \\
\text { approaches }\end{array}$ & $\begin{array}{c}\text { Tsai, Liao \& Han, } \\
\text { 2008: Govindan \& } \\
\text { Chaudhuri, } 2016\end{array}$ \\
\hline & & $\begin{array}{l}\text { Disruption } \\
\text { risks }\end{array}$ & $\begin{array}{c}\text { A process } \\
\text { disruption caused } \\
\text { by natural and } \\
\text { human-made } \\
\text { disasters }\end{array}$ & $\begin{array}{l}\text { Tang, 2006: } \\
\text { Moslemi, Hilmola } \\
\text { \& Vilko, } 2016\end{array}$ \\
\hline & & $\begin{array}{l}\text { Relationship } \\
\text { risks }\end{array}$ & $\begin{array}{l}\text { A few } \\
\text { contradiction and } \\
\text { litigation issues in } \\
\text { supply chain }\end{array}$ & $\begin{array}{c}\text { Tsai, Liao \& Han, } \\
\text { 2008: Govindan \& } \\
\text { Chaudhuri, } 2016\end{array}$ \\
\hline $\begin{array}{c}\text { Value } \\
\text { creation }\end{array}$ & $\begin{array}{c}\text { A greater benefit } \\
\text { of reward from a } \\
\text { certain activity }\end{array}$ & Differentiate & $\begin{array}{c}\text { New services, } \\
\text { ideas, or solutions } \\
\text { unique offer a }\end{array}$ & $\begin{array}{c}\text { Yazdanparast, } \\
\text { Manuj \& Swart, } \\
\text { 2010: Wang, 2014 }\end{array}$ \\
\hline
\end{tabular}




\begin{tabular}{|c|c|c|}
\hline & $\begin{array}{l}\text { value-added to the } \\
\text { target group }\end{array}$ & \\
\hline $\begin{array}{c}\text { Cost } \\
\text { leadership }\end{array}$ & $\begin{array}{l}\text { The elimination of } \\
\text { wasteful elements } \\
\text { in methods of } \\
\text { doing things to } \\
\text { cost reduction }\end{array}$ & $\begin{array}{l}\text { Teresa \& Pilar, } \\
\text { 2018: Vitorino \& } \\
\text { Machado, 2018: } \\
\text { Asian et al., 2019 }\end{array}$ \\
\hline $\begin{array}{l}\text { Flexible } \\
\text { process }\end{array}$ & $\begin{array}{c}\text { Additional services } \\
\text { respond to } \\
\text { customers' } \\
\text { changing needs }\end{array}$ & Wang, 2018 \\
\hline $\begin{array}{l}\text { Provider's } \\
\text { reputation }\end{array}$ & $\begin{array}{c}\text { Customers } \\
\text { acknowledged in } \\
\text { service quality and } \\
\text { brand }\end{array}$ & $\begin{array}{l}\text { Bajec \& Tuljak- } \\
\text { Suban, 2016: } \\
\text { Asian et al.,2019 }\end{array}$ \\
\hline
\end{tabular}

Source: Authors' synthesis, 2021.

\section{Results and Discussion}

The results from the perspective of resource-based view (RBV) describe meaning and relationship of resource sharing, innovation solution, risk management and creating additional value as below.

\subsection{Resource-sharing in Halal logistics}

Resource sharing refers to the extent two partners effectively exchange critical resources about the idea, information, tools and among other issues during supply chain process. A coordination effect to partners effectively working together in order to achieve a corporate set of tasks during the supply chain process is critically linked to partners considering information technology (IT), knowledge sharing and experience to support innovation development of all partners for responding to changing demands. (Olorunniwo \& Li, 2010: Liu, Huo, Liu \& Zhao, 2015 : Peng, Wang, Zahid, Wei \& Elahi, 2020). Karia \& Asaari (2016) found that logistics resources can be divided into tangible and intangible resources including common physical resource, advanced physical resource, knowledge, relational and organizational. These logistics resources lead to an innovation capability from an acquiring valuable and rare resources. Chih, Zwikael, \& Restubog (2019) found that professional service firms and customers interact in creating value with trust in customer support to make sure their needs and safe a balance between resource limitation and expectations. Thus, customer participation is important to improving the performance efficiency and reducing the risks in supply chain. Logistics management is important to increasing the potential to gain a competitive advantage from tangible and intangible resources, by underlining the differentiation from other competitors and 
creating value added for customers and organizations (Ralston, Grawe \& Daugherty, 2013: Chaudhuri, Srivastava, Srivastava \& Parveen, 2016). Logistics resources sharing is a mechanism to drive the organization capabilities and flexibilities in services with following factors:

1) Knowledge sharing. Knowledge sharing is a basic resource including the expertise and ability of logistics service providers (LSPs) to solving problems with a wide of problem-solving tools and problem-solving techniques solve for customers. (Vargo \& Lusch, 2017). Creating value in integrated supply chain, it depends on knowledge sharing to emphasis on interaction with partners of the key success factor in services (Tarmizi, Kamarulzaman, Latiff \& Rahman, 2014: Chih, Zwikael \& Restubog, 2019).

2) Information sharing. Information sharing refers to organization investment in tangible resources. Information sharing is particularly relevant to information technology (IT) as system combination can provide a database to exchange essential information on a platform between partners. (Liu, Huo, Liu \& Zhao, 2015: Wong, Lai, Cheng \& Lun, 2015). Cooperation can encourage the acquisition of new technologies, shorten the R\&D cycle of innovative solution and reduce cooperation conflicts for quickly responding to changes in customers' demand (Pham, Nguyen, McDonald \& Tran-Kieu, 2019).

3) Advance technology and equipment. The key practices of halal logistics must be avoided from non-halal products or material until it reaches the end consumer by separated tools and equipment in operation. Preventive measures are extremely important to make sure that the halal products instill halal quality even throughout the transportation process within the supply chain. (Mohamed, Lim \& Vincent, 2013: Ahmad \& Shariff, 2016). Logistics information technology will be tracking and monitoring the overall logistics activities, an important element for halal logistics performance (Masudin, Fernanda \& Widayat, 2018). Positive service quality will generate perceived value and assurance of customer that leads to loyalty.

\subsection{Innovative solution to Halal logistics}

According to OECD (2018), innovation is considered a new or improved product or process differentiated from the previous product or processes. A new product or process refers to the adoption of technology and the changes in operating practices to create value for products and services. The results of the innovation reflect on operation efficiency through reduced cost and elevated production or service processes with large profit margins in market sharing. The organization plays an important role in promoting innovation to high services potential and competitive advantage, which knowledge, skill, creativity, and experience in technology management develop a traditional differentiator (Ralston, Grawe \& Daugherty, 2013). However, innovation must be imported the basic information necessary to supporting research and development (Luo, 2010: Jaafar, Endut, 
Faisol \& Omar, 2011: Ruiz-Torres, Cardoza, Kuula, Oliver \& Rosa-Polanco, 2017: Vitorino Razzera \& Machado, 2018). The differentiator is a business opportunity with place and time utility value responding to a niche market in a high variety of economic benefits (Kilibarda, Andrejic \& Popovic, 2013). Nowadays, logistics services play a greater role in human daily life, especially a consumption goods logistics management must be controlled to comply with food safety standards from upstream to downstream. The different characteristics of consumption goods should be controlled with a different method. Logistics service providers (LSPS) have been seeking an opportunity to allocated ability and resources management to create value innovation. Ambali \& Bakar (2013) found that the volume of halal food trade was grown-up from the Muslim population worldwide increased, whose population has a higher average income effect to the ability to spending and awareness to selecting of religious goods for good health and good quality. Many non-Muslims are interested in halal products because there is confidence in the standardization of product quality. However, Muslim need to make sure that halal standardization on foods and products is operated according to the Islamic rules and principles for all processes. (Fathi, Zailani, Iranmanesh \& Kanapathy, 2016). Therefore, halal logistics is a competitive advantage of logistics service providers on niche markets. Jaafar et al. (2011) interpret that halal logistics as any service innovation is seen as new and helpful to a particular customer. Halal logistics requires a special practice for managing the supply chain. Logistics service providers (LSPs) must be able to an extensive understanding of the halal principle before action. Halal logistics principle refers to the segregation of halal and non-halal products throughout the process as well as the equipment, machinery, or any tools used to manage the products that do not mix. Halal logistics is a nonpopular service in Thailand's logistics market which challenges both traditional and new processes in the allocation of resources management. Innovation solution is a mechanism to drive the organization's capabilities and flexibility in services thourgh the following factors:

1) Organization factor. Services operations should be aligned with the internal organization resources investing in essential technology, new knowledge and organization structure that it has been supported by a manager and organizational policy (Jaafar, Endut, Faisol \& Omar, 2011: Tan, Razali \& Desa, 2012: Ralston, Grawe \& Daugherty, 2013 : Ruiz-Torres, Cardoza, Kuula, Oliver \& Rosa-Polanco, 2017).

2) Environment factor. Environment factor is a main factor in studying the current competition influencing the decision to change service processes such as the government support for halal standardization (Tan, Razali \& Desa, 2012: Tarmizi, Kamarulzaman, Latiff \& Rahman, 2014). Due to the fierce competition in logistics services industry, innovation creation should be realized considering the positive and negative effect in environment for sustainable competitive advantage (Ralston, Grawe \& Daugherty, 2013).

3) Assurance factor. Logistics services providers are obliged to act responsibly to maintain the right time, right place and right products emphasizing to customers 
HOLISTICA Vol 12, Issue 2, 2021, pp.1-15

assurances (Tan, Razali \& Desa, 2012: Chen, Hsu \& Lee, 2019). Halal assurance needs to be implemented by logistics service providers (LSPs) that strengthen confidence in the safety and integrity of halal products throughout the supply chain and promote the stability both of halal industry and halal businesses (Othman, Shaarani \& Bahron, 2016: Ahmad \& Shariff, 2016).

\subsection{Risk management on Halal logistics}

Risk management is the ability to encountering an opportunity to challenges and prevent potential threats (Andersen, 2009). In industries going on a change trajectory, risk management determines the degree of internal risk exposure (Clifford W. Smith, 1995). The study of risk management of logistics service providers (LSPs), of risks in internal operations of logistics service providers (LSPs) refers to service quality they provide to customers and it is measured though a satisfaction indicator. Regarding risk in services process and asset risks, there are some activities that might incur errors such as documentation, booking and invoicing, regulatory compliance and security compliance, strikes and transport congestion, cargo loss or damage, the unpreparedness of technology to manage information flow and customer lead time (Chaudhuri, Srivastava, Srivastava \& Parveen, 2016). Logistics risk is part of the supply chain risk alongside activities including risk on sourcing, purchasing, production operations, and demand managing that it does not correspond to supply. Ineffective risk management impacts also the responses to customer and might determine increased costs (Chaudhuri, Srivastava, Srivastava \& Parveen, 2016). The research of Tang (2006) and Manuj \& Mentzer (2008) investigated the relationship between risk exposure and firm performance. Their research results show that risk management preparation abate emerging risks and improve responses to crisis with strategy and operational plan. Risk management performance indicators both quantitative and qualitative such as cost, time, quality, flexibility, and innovation mitigate the negative effect of adverse events. New innovations may pose risks from process change. Logistics service providers (LSPs) should consider various factors such as improving the knowledge of workers and the efficiency of tools and equipment in order to build trust with their customers. Although, halal market is continuously growing and there are many research studies about the halal logistics requirements, there are still limitations to its application. Aziz \& Chok (2013) found that risks in halal logistics caused by consistent lack of understanding of halal standards. The research of Othman, Shaarani \& Bahron (2016) and Ahmad \& Shariff (2016) describe that practice in relation to the movement of halal products is very challenging for logistics service providers because there is a lack of collaborative efforts. Thus, one party in supply chain must make sure that the activities are managed according to Shariah law when it is passed onto a different party. (Mohamed, Lim \& Vincent, 2013). Therefore, the factors within the realm of risk management that the logistics service providers should consider are:

1) Process design and planning risk. Process design and planning risk is the internal operational risk of the logistics service provider (LSPs), which prevents the effect of customer dissatisfaction, misusage of information technology systems, process 
flexibility, packaging development and inventory stockouts (Tsai, Liao \& Han, 2008: Govindan \& Chaudhuri, 2016).

2) Disruption risk. Disruption risk is a main factor in risk management. The research results of Moslemi, Hilmola \& Vilko (2016) and Tang (2006) concur that disruption risks are related to one of the following categories natural disaster, terrorist attack, economic crisis and strikes.

3) Relationship risk. Relationship risk has the lowest effect on services quality when logistics services providers (LSPs) provide standardized service operations with a long-time reliability (Tsai, Liao \& Han, 2008). Govindan \& Chaudhuri (2016) describe that relationship risk of LSPs will get feedback from customers including incorrect information, lack of trust and the different culture and language between LSPs and customers.

\subsection{Halal logistics value creation}

According to Michael E. Porter, the value chain is a value system that includes both upstream and downstream operations. Logistics service providers must consider reducing an operating cost and focusing on process efficiency that can add value to final products and services (Thompson, Peteraf, Gamble \& Strickland, 2014). Normally, the greatest potential of value-creating is registered in the phases of introduction and growth of new processes and products. The value added, depending on the level of product or service success that it has a positive or negative effect on the consumer value perception (Kilibarda, Andrejic \& Popovic, 2013). The ability of creating values is a resource of competitive advantage for products and services and it refers to:

1) Differentiation. Differentiation is the result of ideas designed to separate the company's offer from competitors' offers (Kotler, Ang, Leong \& Tan, 1996: Ralston, Grawe \& Daugherty, 2013). A new service is created for specific customers demand in accordance with the expectations and business environment (Yazdanparast, Manuj \& Swartz, 2010), depending on logistics service providers (LSPs) capability to create value from the unique model (Wang, 2018).

2) Cost leadership. Price, advertising, and the introduction of new services strategy are of paramount importance in logistics service providers' operations that define the competitive position of logistics service providers (Wang, 2018). Logistics performance emphasizes strategic management through quality, cost reduction, reduction of non-beneficial processes and building long-term relationships with customers and suppliers (Teresa \& Pilar, 2018: Vitorino Razzera \& Machado, 2018 : Asian, Pool, Nazarpour \& Tabaeeian, 2019).

3) Flexible process. Flexible Process is not based on a single service function. It proposes new services responses to customers' changing needs with different requirements which create a customized/tailored service. A customized service 
refers to specialized service from the resource management process to achieve maximum efficiency (Wang, 2014).

4) Provider's reputation. Price, financial considerations, experience in the same industry, customer service, equipment, continuous improvement, reputation, cultural fit, and market share are criteria and sub-criteria for selecting third-party logistics. Moreover, providers reputation reflects their vision, corporate image, customer assurance and the capacity of building long-term relationships (Bajec \& Tuljak-Suban, 2016: Asian, Pool, Nazarpour \& Tabaeeian, 2019).

\section{Conclusion}

The relationship between resource sharing, risk management, innovation solution to halal logistics and halal logistics value creation is a unique topic in the logistics sector, in Thailand. This study could be applied to future research. It will create a competitive advantage for logistics service providers (LSPs). Moreover, the study exhibits a conceptual framework relevant to halal logistics activities (Figure 1) and the relevant theories are underlined in eight hypotheses below.

H1: Innovation solution to halal logistics has a positive relationship with halal logistics value creation.

H2: Risk management has a positive relationship with halal logistics value creation.

H3: Risk management has a positive relationship with innovation solution to halal logistics.

H4: Resource sharing has a positive relationship with innovation solution to halal logistics.

H5: Resource sharing has a positive relationship with risk management.

H6: Resource sharing has a positive relationship with halal logistics value creation.

H7: Innovation solution to halal logistics is a mediator in the relationship between resource sharing and halal logistics value creation.

H8: Risk management is a mediator in the relationship between resource sharing and halal logistics value creation. 
Figure 1 Research Framework

$\mathrm{H} 7$

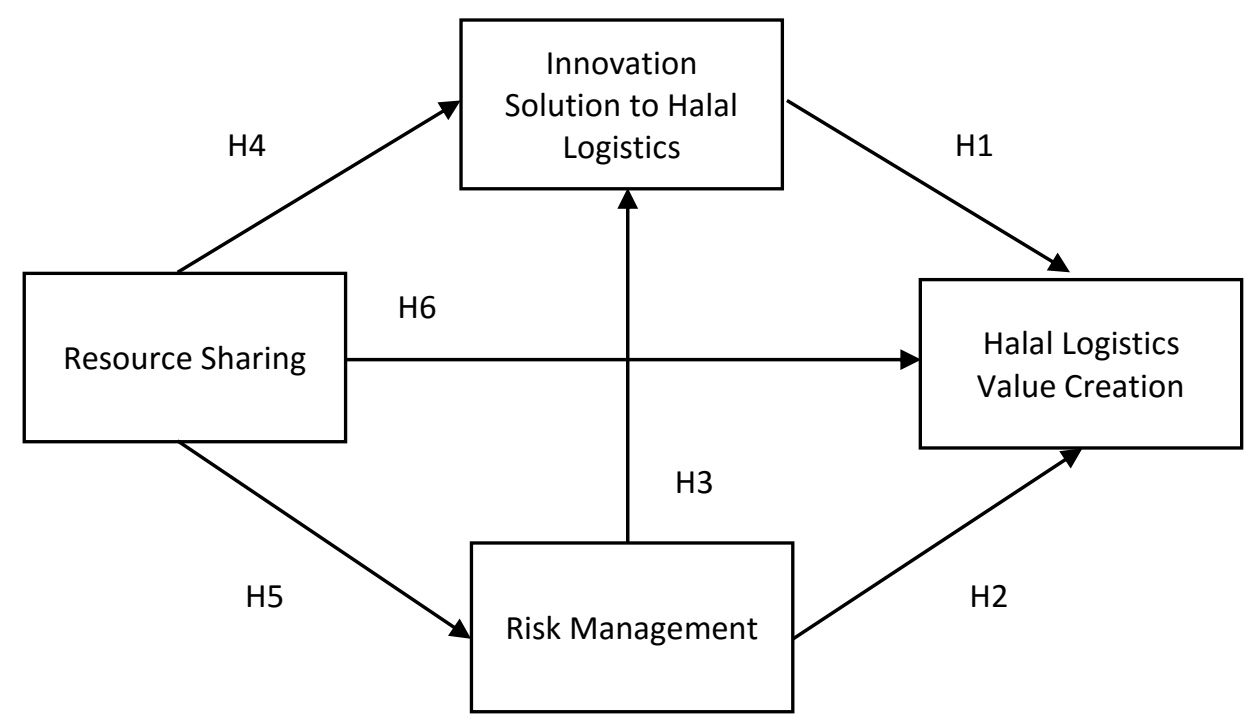

$\mathrm{H} 8$

Source: Authors' concept, 2021.

\section{References}

Ahmad, N., \& Shariff, S. M. (2016). Supply Chain Management: Sertu Cleansing for Halal Logistics Integrity. Procedia Economics and Finance, no. 37: 418-425. doi:10.1016/s22125671(16)30146-0.

Alkhatib, S., Darlington, R., \& Nguyen, T. (2015). Logistics service providers (LSPs) evaluation and selection: Literature review and framework development. Strategic Outsourcing: an international journal, no. 8: 102-134.

Andersen, T.J. (2009). Effective risk management outcomes: exploring effects of innovation and capital structure. Journal of Strategy and Management, no. 2 (4): 352-379.

Ambali, A.R., \& Bakar, A.N. (2013). Halal food and products in Malaysia: People's awareness and policy implications. Intellectual Discourse, no. 21(1): 7-32.

Asian, S., Pool, J. K., Nazarpour, A., \& Tabaeeian, R. A. (2019). On the importance of service performance and customer satisfaction in third-party logistics selection. Benchmarking: An International Journal, no. 26(5): 1550-1564. doi:10.1108/bij-05-2018-0121.

Aziz, Y. A., \& Chok, N. V. (2013). The Role of Halal Awareness, Halal Certification, and Marketing Components in Determining Halal Purchase Intention Among Non-Muslims in Malaysia: A Structural Equation Modeling Approach. Journal of International Food \& Agribusiness Marketing, no. 25(1): 1-23. doi:10.1080/08974438.2013.723997.

Barney, J. (1991). Firm resources and sustained competitive advantage. Journal of Management, no. 17(9): 99-120. doi: 10.1177/014920639101700108. 
HOLISTICA Vol 12, Issue 2, 2021, pp.1-15

Bajec, P., \& Tuljak-Suban, D. (2016). Identification of Environmental Criteria for Selecting a Logistics Service Provider: A Step Forward towards Green Supply Chain Management. Sustainable Supply Chain Management, UK: InTech.

Bernardo, M., \& Farrero, J. M. C. (2015). Analysis of the Relationship between the Integration of Management Systems and the Creation of Value. In International Conference on Logistics, Informatics and Service Sciences (LISS). Barcelona: Spain. doi:10.1109/LISS.2015.7369655

Bowman, C., \& Ambrosini, V. (2000). Value Creation Versus Value Capture: Towards a Coherent Definition of Value in Strategy. British Journal of Management, no. 11: 1-15.

Cengiz, H., Radha, C., \& Ronald G., C. (2004). A Model of Value Creation: Strategic View. Journal of Business Ethics, no. 49: 291-305.

Chang, C.H., Jingjing, X. \& Dong-Ping, S. (2015). Risk analysis for container shipping: from a logistics perspective. International Journal of Logistics Management, no. 26(1): 147-171.

Chaudhuri, A., Srivastava, S. K., Srivastava, R. K., \& Parveen, Z. (2016). Risk propagation and its impact on performance in food processing supply chain. Journal of Modelling in Management, no. 11(2): 660-693. doi:10.1108/jm2-08-2014-0065.

Chen, M. C., Hsu, C. L., \& Lee, L. H. (2019). Service Quality and Customer Satisfaction in Pharmaceutical Logistics: An Analysis Based on Kano Model and Importance-Satisfaction Model. International Journal of Environmental Research and Public Health, no. 16(21). doi:10.3390/ijerph16214091.

Chih, Y.-Y., Zwikael, O., \& Restubog, S. L. D. (2019). Enhancing value co-creation in professional service projects: The roles of professionals, clients and their effective interactions.

International Journal of Project Management, no. 37(5): 599-615. doi:10.1016/j.ijproman.2019.04.001.

Clifford W. Smith, J. (1995). Corporate risk management: theory and practice. The Journal of Derivatives, no.1 (summer 1995): 21-30.

Etokudoh, E. P., Boolaky, M., \& Gungaphul, M. (2017). Third Party Logistics Outsourcing: An Exploratory Study of the Oil and Gas Industry in Nigeria. SAGE Open, no. 7(4): 1-19. doi:10.1177/2158244017735566

Fathi, E., Zailani, S., Iranmanesh, M., \& Kanapathy, K. (2016). Drivers of consumers' willingness to pay for halal logistics. British Food Journal, no. 118(2): 464-479. doi:10.1108/bfj-06-20150212.

Govindan, K., \& Chaudhuri, A. (2016). Interrelationships of risks faced by third party logistics service providers: A DEMATEL based approach. Transportation Research Part E: Logistic and Transportation Review, no. 90: 177-195. doi:10.1016/j.tre.2015.11.010.

Ho, L.-H., \& Chang, P.-Y. (2015). Innovationa Capabilities, Service Capabilities and Corporate Perfprmance in Logistics Services. The International Journal of Organizational Innovation, no. 7(3): 24-33.

Jaafar, H. S., Endut, I. R., Faisol, N., \& Omar, E. N. (2011). Innovation in logistics services - halal logistics. Proceedings of the 16th International Symposium on Logistics (ISL): 844-851.

KASIKORN Research Center. n.d. "K SME Analysis". Accessed November 10, 2020. https://www.kasikornbank.com/th/business/sme/KSMEKnowledge/article/KSMEAnalysis/ Documents/Thai-SME-Opportunity_Halal-Market.pdf.

Karia, N., \& Asaari, M. H. A. H. (2016). Halal value creation: its role in adding value and enabling logistics service. Production Planning \& Control, no. 27(9): 677-685. doi:10.1080/09537287.2016.1166276. 
Karia, N., Wong, C. Y., Asaari, M. H. A. H., \& Lai, K.-H. (2015). The Effects of Resource Bundling on Third-Party Logistics Providers' Performance. International Journal of Engineering Business Management, no. 7(9): 1-14. doi:10.5772/60041.

Kilibarda, M. J., Andrejic, M. M., \& Popovic, V. J. (2013). Creating and Measuring Logistics Value. Logic: 197-202.

Kotler, P., Ang, S. H., Leong, S. M., \& Tan, C. T. (1996). Marketing management. Upper Saddle River, NJ: Prentice Hall.

Lai, K.H., Wong, C.W. \& Cheng, T.C. (2010). Bundling digitized logistics activities and its performance implications. Industrial Marketing Management, no. 39(2): 273-286.

Liu, C., Huo, B., Liu, S., \& Zhao, X. (2015). Effect of information sharing and process coordination on logistics outsourcing. Industrial Management \& Data Systems, no. $115(1)$ : 41-63. doi:10.1108/imds-08-2014-0233.

Luis, L., Alan, C., Erin, O.C. \& Sandra, S. (2011). The Future of the Global Muslim Population: Forum on Religion \& Public Life, Washington, D.C, Columbia. Accessed November 10, 2020. https://www.pewforum.org/.

Luo, Z. (2010). Service Science and Logistics Informatics: Innovative Perspectives. USA: IGI Global.

Manuj, I. \& Mentzer, J.T. (2008). Global supply chain risk management strategies. International Journal of Physical Distribution \& Logistics Management, no. 38(3): 192- 223.

Masudin, i., Fernanda, F. W., \& Widayat, W. (2018). Halal Logistics Performance and Customer Loyalty: From the Literature Review to a Conceptual Framework. International Journal of Technology, no. 9(5). doi:10.14716/ijtech.v9i5.1919.

Mohamed, S. A. T., Lim, R., \& Vincent, K. Z. (2013). Qualitative Research on Critical Issues in Halal Logistics. Journal of Emerging Economies and Islamic Research, no. 1(2): 1-20.

Moslemi, A., Hilmola, O.-P., \& Vilko, J. (2016). Risks in emerging markets: logistics services in the Mediterranean region. Maritime Business Review, no. 1(3): 253-272. doi:10.1108/mabr-082016-0017.

Muslimpopulation (2018). World Muslim Population. Accessed September 25, 2020. http://www.muslimpopulation.com/World/.

National Food Institute. n.d. Halal Food Industry Situation. Accessed September 25, 2020. http://thaihalalfoods.com/TH/index.php.

OECD (2018). Oslo manual 2018: Guidelines for collecting reporting and using data on innovation. Accessed November 10, 2020. https://www.oecd.org/sti/inno/oslo-manual-2018-info.pdf.

Olorunniwo, F. O., \& Li, X. (2010). Information sharing and collaboration practices in reverse logistics. Supply Chain Management: An International Journal, no. 15(6): 454-462. doi:10.1108/13598541011080437.

Othman, B., Shaarani, S. M., \& Bahron, A. (2016). Evaluation of knowledge, halal quality assurance practices and commitment among food industries in Malaysia. British Food Journal, no. 118(8): 2033-2052. doi:10.1108/bfj-12-2015-0496.

Peng, B., Wang, Y., Zahid, S., Wei, G., \& Elahi, E. (2020). Platform ecological circle for cold chain logistics enterprises: the value co-creation analysis. Industrial Management \& Data Systems, no.120(4):675 - 691. doi:10.1108/imds-10-2019-0531.

Pham, H. C., Nguyen, T.-T., McDonald, S., \& Tran-Kieu, N. Q. (2019). Information Sharing in Logistics Firms: An Exploratory Study of the Vietnamese Logistics Sector. The Asian Journal of Shipping and Logistics, no.35(2): 87-95. doi:10.1016/j.ajsl.2019.06.001.

Phillips, S., Thai, V. V., \& Halim, Z. (2019). Airline Value Chain Capabilities and CSR Performance: The Connection Between CSR Leadership and CSR Culture with CSR Performance, Customer 
Satisfaction and Financial Performance. The Asian Journal of Shipping and Logistics, no. 35(1): 30-40. doi:10.1016/j.ajsl.2019.03.005.

Ralston, P. M., Grawe, S. J., \& Daugherty, P. J. (2013). Logistics salience impact on logistics capabilities and performance. The International Journal of Logistics Management, no. 24(2): 136-152. doi:10.1108/ijlm-10-2012-0113.

Ruiz-Torres, A. J., Cardoza, G., Kuula, M., Oliver, Y., \& Rosa-Polanco, H. (2017). Logistic services in the Caribbean region An analysis of collaboration, innovation capabilities and process improvement. Academia Revista Latinoamericana de Administración, no. 31(3): 534-552. doi:10.1108/ARLA-03-2017-0078.

Talib, M. S. A., Rahim, M. A. R. A., Chin, T. A., \& Hamid, A. B. A. (2017). Logistics service providers (LSPs) perceptions on halal logistics certification. International Journal of Logistics Economics and Globalisation, no. 6(4): doi:10.1504/ijleg.2017.10009119.

Tang, C.S. (2006). Perspectives in supply chain risk management. International Journal of Production Economics, no. 103(2): 451-488.

Tan, M. I. I., Razali, R. N., \& Desa, M. I. (2012). Factors Influencing ICT Adoption in Halal Transportations: A Case Study of Malaysian Halal Logistics service providers (LSPs). International Journal of Computer Science, no. 9(1): 62-71.

Tarmizi, H. A., Kamarulzaman, N. H., Latiff, I. A., \& Rahman, A. A. (2014). Factors Influencing Readiness towards Halal Logistics among Food-based Logistics Players in Malaysia. UMK Procedia, no.1: 42-49. doi:10.1016/j.umkpro.2014.07.006.

Teresa, V.-B., \& Pilar, R.-T. 2018. "The relationship between logistics and marketing performance in the supply chain. Different paths for manufacturers and distributors". UCJC BUSINESS AND SOCIETY REVIEW, no.4: 90-135. doi:10.3232/UBR.2018.V15.N4.03

Tian, Y., Ellinger, A. E., \& Chen, H. (2010). Third party logistics provider customer orientation and customer firm logistics improvement in China. International Journal of Physical Distribution \& Logistics Management, no. 40(5): 356-376. doi:10.1108/09600031011052822.

Tsai, M. C., Liao, C. H., \& Han, C. S. (2008). Risk perception on logistics outsourcing of retail chains: model development and empirical verification in Taiwan. Supply Chain Management: An International Journal, no. 13(6): 415-424. doi:10.1108/13598540810905679.

Thompson, A.A., Peteraf, M.A., Gamble, J.E. \& A. J. Strickland III. (2014). Crafting \& Executive Strategy: Concepts and Readings 20th edition. United States of America: McGraw-Hill Education.

Vargo, S.L. \& Lusch, R.F. (2017). Service-dominant logic 2025. International Journal of Research in Marketing, no.34 (1): 46-67.

Vitorino Razzera, A., \& Machado, M. A. (2018). The role of TPLs in innovative logistics solutions in importation". Innovation \& Management Review, no.15(1): 73-91. doi:10.1108/inmr-022018-005.

Wang, L. (2014). Research on the Development Strategy of Logistics Firms in China. Open Journal of Social Sciences, no. 2(9): 253-257. doi:10.4236/jss.2014.29042.

Wang, S. (2018). Developing value added service of cold chain logistics between China and Korea. Journal of Korea Trade, no. 22(3): 247-264. doi:10.1108/jkt-03-2018-001.

Wong, C.W.Y., Lai, K.-h., Cheng, T.C.E. \& Lun, Y.H.V. (2015). The role of IT-enabled collaborative decision making in inter-organizational information integration to improve customer service performance. International Journal of Production Economics, no. 159(1): 56-65.

Yazdanparast, A., Manuj, I., \& Swartz, S. M. (2010). Co-creating logistics value: a service-dominant logic perspective. The International Journal of Logistics Management, no. 21(3): 375-403. doi:10.1108/09574091011089808. 